1 Bazelly B, Marchand M, de Riberolles C, et al. Accidents neurologiques a repetition par fistules arterio-veineuses pulmonaires. Nouve Presse Med 1981;10: tion par

2 Gomes MR, Bernatz PE, Dines DE. Pulmonary arterio-venous fistulas. Ann Thorac Surg 1969;7:582-90.

3 Moyer JH, Glantz G, Brest AN. Pulmonary arterio-venous fistulas. Am $\mathcal{F}$ Med $1962 ; 32: 417-35$. 4 Przybojewzki JZ, Maritz F. Pulmonary arterio-venous fistulas. $S$ Afr Med $\mathcal{f}$
1980;57:366-73.

(Accepted 13 February 1985)

Atkinson Morley's Hospital, London SW20 0NE

M S DENNIS, MB, MRCP, senior house officer in neurology

Correspondence to: Dr M S Dennis, 16 St Peter's Court, 93 King's Avenue, London SW4 8EH.

\section{Stress, cortisol concentrations, and lymphocyte subpopulations}

The aetiology of rheumatoid arthritis is almost certainly multifactorial, so that established genetic factors and suspected infective agents do not preclude the possibility of psychological factors also influencing the onset of disease. ${ }^{1}$ This influence may be mediated by stress modifying the responses of the immune system. ${ }^{2}$ Before starting further studies of people with disease we therefore decided to investigate the responses of $\mathrm{T}$ lymphocyte populations in normal students under stress.

\section{Subjects, methods, and results}

We invited medical students on the second day of their clinical course in a medical school new to them to participate in the study. All 35 with surnames beginning $A$ to $G$ were approached: 33 accepted, attending during their first week (October 1983). Twenty eight second year students served as

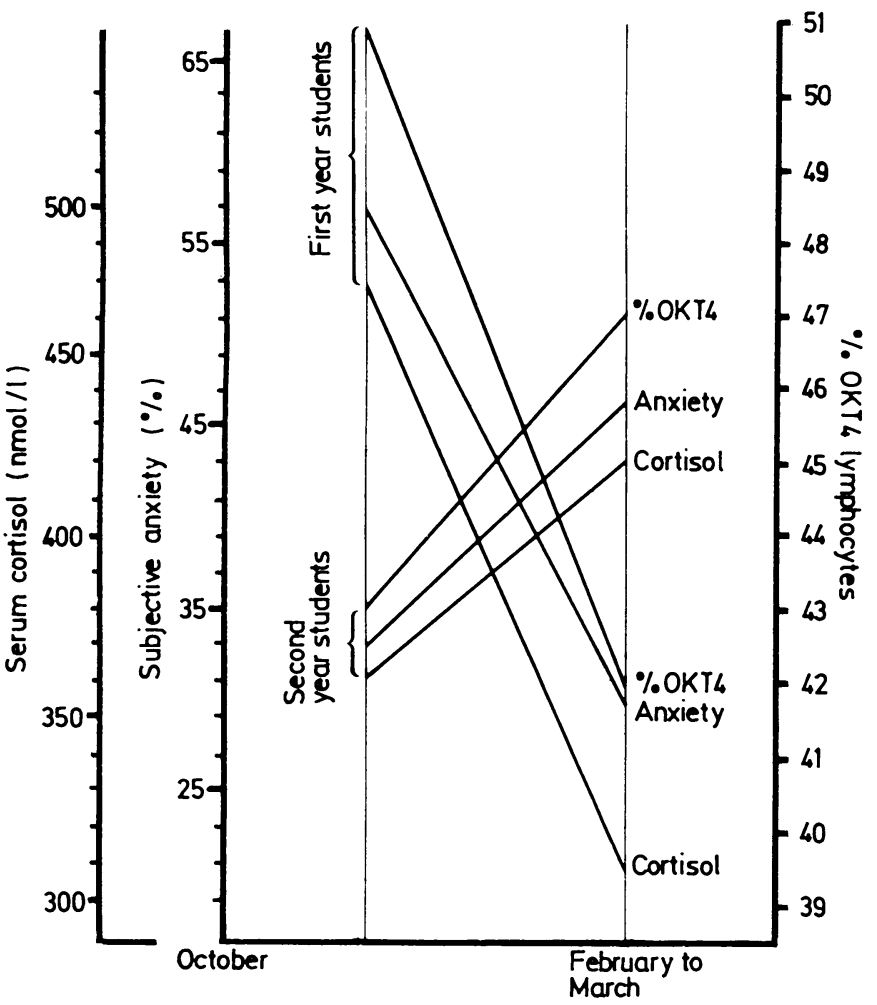

Subjective anxiety scores, serum cortisol concentrations, and proportions of OKT4 lymphocytes in first and second year students.

Conversion: SI to traditional units-Cortisol: $1 \mathrm{nmol} / 1 \approx 0.036 \mu \mathrm{g} / 100 \mathrm{ml}$ controls. Thirty one of the first year students and 22 of the second year students were tested again about four months later (in February and March 1984). Each student assessed his or her subjective anxiety on that day on an uncalibrated $10 \mathrm{~cm}$ visual analogue scale, the extremes of which were marked

"The day of my life I felt least /most anxious or tense." The score was recorded as zero (least) to 100 (most). Personal and family histories of atopic disorder were asked for and no difference was found between first and second year students.

All students were seen between 11 am and $1 \mathrm{pm}$ to avoid the effects of diurnal variation. Total leucocyte and lymphocyte counts were determined using a Coulter S Plus counter. Parallel heparinised blood samples were separated on discontinuous Ficoll-metrizoate (Triosil) gradients, incubated with fluoresceinated monoclonal anti-T cell antibodies (Ortho-Mune OKT series) without the addition of any fetal calf serum, and analysed on the cytofluorograph (FACS 420; Becton Dickinson). ${ }^{3}$ Scatter gates set on the 90 light scatter profile were used to minimise contamination of cell preparations with non-lymphocytic cells. The heparinised plasma was frozen and used to measure serum cortisol concentrations.

At the first testing nine first year students and one second year student did not have lymphocyte subpopulation estimations done, but their anxiety and cortisol measurements were included in the calculation of those means.

The Mann-Whitney test, two tailed, was used to compare the first with the second year students at the first and second visits, while Wilcoxon's matched pairs test, two tailed, was used to compare the first with the second visit of both groups of students.

The figure illustrates the differences in means among the four sets of results (though the means were not used in the statistics). The new students showed significantly higher subjective anxiety scores and cortisol concentrations than the second year students and than themselves at the second visit (all $\mathrm{p}$ values $<0.005$ ). This finding was associated with a significantly raised proportion of OKT 4 cells when compared with the second year students at the same time $(p=0.0001)$ and with themselves a few months later $(\mathrm{p}<0.005)$. The second year students showed increases in anxiety, cortisol values, and proportions of OKT 4 cells at their second visit, probably because they were approaching an examination, but the increases did not reach significance. There were no significant changes in white cell counts, lymphocyte counts, or proportions of OKT8 cells.

\section{Comment}

Students during their first week experienced a high level of psychological and physiological arousal, shown by raised subjective anxiety scores and serum cortisol concentrations. These features were associated with a significant increase in the proportion of OKT4 cells (helper T lymphocytes).

Not all psychological states produce similar responses: for example, Kronfol and House, commenting on our preliminary results, ${ }^{4}$ reported that they had found no difference in the percentage of lymphocyte subsets when comparing depressed people with controls. ${ }^{5}$

Probably our finding is only part of a far more complicated immune response to stress. In many diseases (well represented by rheumatoid arthritis) the influence of stress and other emotional factors on the immune system may prove to be of fundamental importance in both susceptibility to disease and subsequent fluctuations during the course of disease.

Baker GHB, Brewerton DA. Rheumatoid arthritis: a psychiatric assessment. Br Med F 1981;282:2014-6.

Baker GHB. Life events before the onset of rheumatoid arthritis. Psychother

3 Hoffman RA, Kung PC, Hansen WP, Goldstein G. Simple and rapid measurement of human T-lymphocytes and their subclasses in peripheral blood. Proc

4 Baker GHB, Byrom NA, Irani MS, et al. Stress, cortisol, and lymphocyte sub-

populations. Lancet $1984 ; \mathrm{i}: 574$.

Kronfol Z, House JD. Depression, cortisol, and immune function. Lancet 1984; i:1026-7.

(Accepted 30 fanuary 1985)

Charing Cross and Westminster Medical School, London

G H B BAKER, MD, FRCPSYCH, consultant psychiatrist

M S IRANI, BSC, MRCP, senior registrar in rheumatology

N A BYROM, BTECH, PHD, lecturer in chemical immunology

N M NAGVEKAR, BSC, research assistan

R J WOOD, BSC, computer programmer

J R HOBBS, MD, FRCPATH, professor of chemical immunology

D A BREWERTON, MD, FRCP, consultant rheumatologist

Correspondence to: Dr G H B Baker, Department of Rheumatology, Westminster Hospital, London SW1P 2AP. 